\title{
A Study on Oxidation of Tetramethylammonium Hydroxide (TMAH) using UV/Persulfate
}

\section{Hyo-yeon $\mathrm{Choi}^{\odot} \cdot$ Daewon Pak ${ }^{\dagger}$}

Department of Environmental Energy Engineering, Graduate School of Energy \& Environment, Seoul National University of Science \& Technology

(Received July 15, 2020; Revised September 28, 2020; Accepted October 5, 2020)

Objective: In order to efficiently remove TMAH from the wastewater generated by the TFT-LCD manufacturing process, the oxidation of TMAH was tested by applying an UV/persulfate. The optimum reaction conditions for high concentration TMAH oxidation were investigated by evaluating and comparing the removal efficiency according to the factors affecting TMAH oxidative degradation.

Methods : In this study, TMAH was decomposed by sulfate radical $\left(\mathrm{SO}_{4}^{-{ }^{-}}\right)$and hydroxyl radical $\left(\mathrm{OH}^{\bullet}\right)$ generated $^{\circ}$ from persulfate activated by UV. Factors affecting on the treatment efficiency were try to be optimized by comparing and evaluating the removal efficiency depending on the initial $\mathrm{pH}$, oxidant concentration, and initial TMAH concentration.

Results and Discussion: Depending on initial $\mathrm{pH}(2,7,12)$, persulfate addition $(0,50,100,150,200 \mathrm{mM})$, initial TMAH concentration $(100,300,500,700 \mathrm{mg} / \mathrm{L})$ degradation rates of TMAH were compared. When UV/persulfate was applied, the removal efficiency of TMAH was close to $90 \%$ regardless of the initial $\mathrm{pH}$ and, at

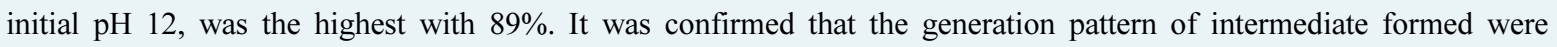
different depending on the initial $\mathrm{pH}$. When the oxidizing agent was not added, there was little change in TMAH concentration. The removal efficiency was highest when $100 \mathrm{mM}$ persulfate was added. However the efficiency was rather low when $150 \mathrm{mM}$ persulfate was added. When the initial TMAH concentration was $100 \mathrm{mg} / \mathrm{L}$, it was decreased within 150 minutes. As the initial concentration increased, the removal efficiency and reaction rate constant decreased.

Conclusions: As a results, during the oxidation of $750 \mathrm{mg} / \mathrm{L}$ TMAH by using UV/persulfate, the removal efficiency was highest with initial $\mathrm{pH} 12$ and $100 \mathrm{mM}$ of persulfate addition.

Keywords: TMAH, UV/persulfate, Sulfate Radical $\left(\mathrm{SO}_{4}^{-}{ }^{-}\right)$, Hydroxyl Radical $\left(\mathrm{OH}^{\bullet}\right)$, Demethylation

The Korean text of this paper can be translated into multiple languages on the website of http://jksee.or.kr through Google Translator. 


\title{
연구논문
}

\section{과황산염(persulfate)의 UV 활성화를 이용한 수산화테트라메틸암모늄(TMAH) 산화 반응 연구}

\author{
최효연 ${ }^{\odot}$. 박대원 ${ }^{\top}$ \\ 서울과학기술대학교 에너지환경대학원 에너지환경공학과
}

목적: TFT-LCD의 제조공정에서 현상액으로 쓰여 배출되는 $500 \mathrm{mg} / \mathrm{L}$ 이상의 TMAH 폐수를 효율적으로 제거하기 위해 UV/persulfate를 적용하여 TMAH의 산화반응 특성을 알아보았고 TMAH 산화반응에 미치는 영향인자에 따른 제거효율을 평가, 비교함으로써 최적의 처리조건을 도출하고자 하였다.

방법 : 본 연구에서는 산화제 과황산염(persulfate)을 $\mathrm{UV}$ 로 활성화하여 생성된 황산염 라디칼( $\left.\mathrm{SO}_{4}{ }^{-}\right)$과 수산화 라디 칼 $\left(\mathrm{OH}^{\circ}\right)$ 을 발생시켜 $\mathrm{TMAH}$ 를 산화반응을 유도하였고 산화반응에 대한 영향인자로 초기 $\mathrm{pH}$, 산화제 농도, 초기 $\mathrm{TMAH}$ 농도 등을 조절하여 나타난 제거효율을 비교, 평가하여 처리조건을 최적화하였다.

결과 및 고찰 : UV/persulfate를 이용한 TMAH 산화반응에서 초기 $\mathrm{pH}(2,7,12)$, persulfate 주입량 $(0,50,100,150$, $200 \mathrm{mM})$, 초기 TMAH 농도 $(100,300,500,700 \mathrm{mg} / \mathrm{L})$ 에 따른 제거효율을 비교하였다. UV/persulfate 적용 시 초기 $\mathrm{pH}$ 조절에 상관없이 $90 \%$ 에 가까운 처리효율을 보였으며 그 중 알칼리 조건일 때 제거율이 $89 \%$ 로 가장 높은 반응 속도상수로 나타났다. 초기 $\mathrm{pH}$ 에 따라 중간생성물의 생성 경향이 서로 다른 것으로 나타났다. Persulfate를 주입하 지 않았을 때는 TMAH 농도변화가 거의 없었으며 persulfate $100 \mathrm{mM}$ 를 주입하였을 때 제거효율이 가장 높았으며 $150 \mathrm{mM}$ 주입하였을 때 오히려 효율이 낮게 나타났다. 또한 초기 TMAH 농도 $100 \mathrm{mg} / \mathrm{L}$ 일 때 150 분 이내에 모두 감소하였고 초기 농도가 높아질수록 제거효율 및 반응속도상수가 낮아지는 경향을 보였다.

결론: 본 연구의 결과를 통해 UV/persulfate를 이용하여 $750 \mathrm{mg} / \mathrm{L} \mathrm{TMAH} \mathrm{산화반응} \mathrm{시} \mathrm{초기} \mathrm{pH}$ 가 증가할수록 제 거효율이 상승하고 persulfate 주입농도가 $100 \mathrm{mM}$ 일때 제거효율이 가장 높은 것으로 나타났다.

주제어: TMAH, UV/persulfate, 황산염라디칼 $\left(\mathrm{SO}_{4}^{-{ }^{-}}\right)$, 수산화라디칼( $\left(\mathrm{OH}^{*}\right)$, 탈메틸화

\section{1. 서론}

최근 전자제품에 대한 수요가 증가함에 따라 TFT-LCD (Thin Film Transistor Liquid Crystal Display) 산업이 빠르게 성장하고 있다. TFT-LCD의 제조공정은 매우 복잡하고 섬 세하며 다양한 장치들을 포함하고 있으며 다양한 유기 용제 가 사용되어 그에 따른 폐수가 다량 생성되고 있다. 이 중 TMAH (Tetramethyl ammonium hydroxide)는 폐수에 유입 되는 질소의 성분으로서, TFT 현상 공정 중 포토레지스트 (Photo resist)의 현상액(developer)으로 사용되고 있다. TMAH 는 높은 알칼리성을 가진 유기 아민계 용액으로, 화학적으 로 안정적인 화합물인 동시에 생물학적 분해가 어려운 난분 해성 물질로 그 농도가 증가하면서 독성을 배출하는 물질이 기도 하다. 또한 구조가 매우 안정하기 때문에 공정 중 거의 변형 없이 배출되지만 분자 구조 속에 질소를 포함하고 있
기 때문에 분해 시 암모니아성 질소를 생성하고 있다. ${ }^{1)}$

$\mathrm{TMAH}$ 를 함유한 폐수는 호기성 생분해 ${ }^{2}$, 혐기성 생분해 ${ }^{3)}$, 촉매산환) 광촉매 분해(5), 이온교환수지 ${ }^{6}$ 등으로 처리할 수 있다고 보고되었다. 최근에는 강력한 산화제를 이용한 고도 산화공정(Advanced oxidation processes, AOPs)으로 처리하 는 방안이 제시되고 있으며 이는 유기 오염물 제거에 우수 한 성능을 나타내어 그에 대한 연구가 활발하게 이루어지고 있다.

AOPs는 반응성이 매우 높은 자유라디칼 산화제를 사용하 여 오염물질을 제거하는 원리로 주로 Hydroxyl 라디칼 $\left(\mathrm{HO}^{*}\right)$ 에 기초한 메커니즘을 가지고 있다. $\mathrm{HO}^{\circ}$ 은 $2.8 \mathrm{~V}$ 의 산화환 원 전위(oxidation-reduction potential)를 갖는 강한 산화제로 서 유기화합물의 구조를 파괴할 수 있다. 최근에는 sulfate 라디칼 $\left(\mathrm{SO}_{4}^{-{ }^{-*}}\right)$ 기반으로 하는 기술이 주목을 받고 있다. $\mathrm{SO}_{4}^{-}$ 를 생산할 수 있는 persulfate 음이온 $\left(\mathrm{S}_{2} \mathrm{O}_{8}{ }^{2-}\right)$ 은 물에 대한 용 
해도가 높고 넓은 $\mathrm{pH}$ 범위에도 적용이 가능하며 산화환원 전위가 그 자체로 $2.01 \mathrm{~V}(\mathrm{Eq}$. (1))인 강력한 산화제로서 토 양과 지하수에 존재하는 다양한 유기 오염 물질을 분해하 는데 효과가 있다고 알려져 기존의 널리 이용된 오존과 과 산화수소 등을 대체할 산화제로 관심이 높아지고 있다. ${ }^{7-9)}$ $\mathrm{HO}^{\circ}$ 과 비교하여 $\mathrm{SO}_{4}{ }^{-}$은 활성화 방법에 따라 동일하거나 훨씬 높은 산화환원 전위 $\left(E^{0} \sim 3.1 \mathrm{~V}\right)$ 를 가지고 있으며 $\mathrm{SO}_{4}{ }^{-}$ 는 특정한 경우 $\mathrm{HO}^{*}$ 보다 더 높은 선택성과 더 긴 반감기를 가질 수 있다. 따라서 $\mathrm{SO}_{4}^{-}$는 새로이 대두되고 있는 오염 물질을 물질이나 난분해성 물질을 분해하는데 유사하거나 더 나은 능력을 보일 것으로 예상되고 있다. ${ }^{10,11)}$

Persulfate를 활성화하여 $\mathrm{SO}_{4}{ }^{-*}$ 을 생성하는 방법에는 열, 전이금속, Ultraviolet (UV) 등이 있으며, 그 중 UV 활성 화하는 방법으로 폐수의 유기오염물질을 분해하는 사례가 많아지고 있다. Dionysiou 등은 $\mathrm{UV}$ 광분해 및 $\mathrm{AOP}$ (예: $\mathrm{UV} / \mathrm{TiO}_{2}, \mathrm{UV} / \mathrm{H}_{2} \mathrm{O}_{2}, \mathrm{UV} / \mathrm{S}_{2} \mathrm{O}_{8}{ }^{2-}, \mathrm{UV} / \mathrm{HSO}_{5}{ }^{-}$)에 의해 유기오염 물질을 분해 및 평가하여 보고하였는데 이러한 $\mathrm{UV} /$ peroxide 시스템 중에서 $\mathrm{UV} / \mathrm{S}_{2} \mathrm{O}_{8}{ }^{2-}$ 는 일반적으로 동일한 몰 또는 질 량 농도의 Peroxide 산화제에서 오염물질을 제거하는 가장 효과적인 공정을 보여주었다고 제시하였다. ${ }^{12-14)}$

Persulfate을 활성화하는데 양자수율은 중요한 요소로 작 용한다. 양자수율은 광에 의한 현상이 일어날 때 일어난 현 상횟수에 대해 흡수된 광자의 수에 대한 비율을 나타낸 것 으로 UV 파장이 양자수율에 영향을 미친다. Sulfate 라디칼 의 양자수율은 $248 \sim 351 \mathrm{~nm}$ 범위에서 $\mathrm{UV}$ 파장이 증가할 수록 감소한다고 보고되었으며 최대 양자수율은 248과 $253.7 \mathrm{~nm}$ 파장에서 약 1.4 로 일반적으로 $254 \mathrm{~nm}$ 파장이 $\mathrm{SO}_{4}{ }^{-}$방사 파장으로 사용되고 있다. ${ }^{10)}$

$\mathrm{UV}$ 에 의한 persulfate의 활성화에는 두 가지 메커니즘이 관련될 수 있다. 첫 번째는 UV 에너지를 가해주면서 O-O bond가 분열되어 1 mole의 persulfate는 2 mole의 $\mathrm{SO}_{4}{ }^{-}$을 생성할 수 있고(Eq. (2)) 두 번째는 물분자로부터 생성된 수 소 원자(Eq. (3))가 persulfate와 반응하여 $\mathrm{SO}_{4}^{-{ }^{-}}$을 발생시킬 수 있다(Eq. (4)). 또한 persulfate는 다양한 활성화를 통해 알칼리 조건에서 $\mathrm{HO}^{*}$ 로 추가적으로 전환할 수 있는 특성 (Eq. (5),(6))이 있다. 따라서 산성 조건에서는 $\mathrm{SO}_{4}{ }^{-}$가 1차 적으로 반응하지만 중성조건 이상에서는 $\mathrm{SO}_{4}^{-}$과 $\mathrm{HO}^{*}$ 모 두 유기오염 물질의 분해에 기여하게 된다. ${ }^{10,11)}$

$$
\begin{aligned}
& \mathrm{S}_{2} \mathrm{O}_{8}{ }^{2-}+2 \mathrm{e}^{-} \rightarrow 2 \mathrm{SO}_{4}{ }^{2-} \quad E^{0}=2.01 \mathrm{~V} \\
& \mathrm{~S}_{2} \mathrm{O}_{8}{ }^{2-} \stackrel{U V}{\longrightarrow} 2 \mathrm{SO}_{4}^{-} \quad E^{0}=2.4 \mathrm{~V} \\
& \mathrm{H}_{2} \mathrm{O} \rightarrow \mathrm{H}^{\cdot}+\mathrm{HO}^{\cdot} \\
& \mathrm{S}_{2} \mathrm{O}_{8}{ }^{2-}+\mathrm{H}^{\cdot} \rightarrow \mathrm{SO}_{4}^{-{ }^{-}}+\mathrm{SO}_{4}{ }^{2-}+\mathrm{H}^{+}
\end{aligned}
$$

$$
\text { All pH : } \mathrm{SO}_{4}{ }^{-\bullet}+\mathrm{H}_{2} \mathrm{O} \rightarrow \mathrm{SO}_{4}{ }^{2-}+\mathrm{HO}^{\bullet}+\mathrm{H}^{+}
$$

$$
\text { Alkaline } \mathrm{pH}: \mathrm{SO}_{4}^{-}+\mathrm{OH}^{-} \rightarrow \mathrm{SO}_{4}{ }^{2-}+\mathrm{HO}^{-}
$$

$\mathrm{UV} / \mathrm{S}_{2} \mathrm{O}_{8}{ }^{2-}$ 을 이용한 TMAH 분해는 $\mathrm{SO}_{4}^{-{ }^{-}}$의 공격으로 인한 탈메틸화경로(Demethylation)를 통해 발생된다. 이 경로는 TMAH가 중간매개체인 Trimethylamine (TMA, $\left.\left(\mathrm{CH}_{3}\right)_{3} \mathrm{~N}\right)$ 으 로 분해된 후 dimethylamine (DMA, $\left.\left(\mathrm{CH}_{3}\right)_{2} \mathrm{NH}\right)$, methylamine $\left(\mathrm{MMA}, \mathrm{CH}_{3} \mathrm{NH}_{2}\right)$ 및 암모니아 $\left(\mathrm{NH}_{3}\right)$ 로 점진적으로 분해되는 반응 메커니즘이다. 또한, 탈메틸 경로로부터 생성된 TMA 라디칼 $\left(\left(\mathrm{CH}_{3}\right)_{3} \mathrm{~N}^{+}\right)$은 산 촉매 가수분해 반응을 겪으면서 trimethylamine N-Oxide $\left(\left(\mathrm{CH}_{3}\right)_{3} \mathrm{~N}^{+} \mathrm{O}^{-}\right)$를 형성하며(Eq. (7)) 뒤이은 탈메틸화반응으로 dimethyl nitroxide $\left(\left(\mathrm{CH}_{3}\right)_{2} \mathrm{~N}^{+} \mathrm{O}\right)$ 와 $\mathrm{CH}_{3} \mathrm{~N}^{+} \mathrm{O}^{\circ}$ 를 생성하게 된다(Eq. (8)). 그리고 추가적인 $\mathrm{CH}_{3} \mathrm{~N}^{+} \mathrm{O}^{-}$ 의 산 촉매 가수분해(Eq. (9))와 탈메틸화반응을 거쳐(Eq. (10)) 최종적으로 $\mathrm{NO}_{3}{ }^{-}$으로 이어진다고 보고되었다(Eq. (11)). ${ }^{15,16)}$

$$
\begin{aligned}
& \left(\mathrm{CH}_{3}\right)_{3} \mathrm{~N}^{+} \cdot+\mathrm{H}_{3} \mathrm{O}^{+} \rightarrow\left(\mathrm{CH}_{3}\right)_{3} \mathrm{~N}^{+} \mathrm{O}^{-}+3 \mathrm{H}^{+} \\
& \left(\mathrm{CH}_{3}\right)_{3} \mathrm{~N}^{+} \mathrm{O}^{-} \stackrel{\text { demethylation }}{\longrightarrow} \\
& \left(\mathrm{CH}_{3}\right)_{2} \mathrm{~N}^{+} \mathrm{O} \\
& \stackrel{\text { demethylation }}{\longrightarrow}(\mathrm{C} \\
& \left(\mathrm{CH}_{3}\right) \mathrm{N}^{+} \mathrm{O}^{-}+\mathrm{H}_{3} \mathrm{O}^{+} \rightarrow\left(\mathrm{CH}_{3}\right) \mathrm{N}^{+} \mathrm{O}_{2}^{-}+3 \mathrm{H}^{+} \\
& \left(\mathrm{CH}_{3}\right)^{+} \mathrm{N}_{2}^{-} \stackrel{\text { demethylation }}{\longrightarrow} \mathrm{NO}_{2}^{-\cdot} \\
& \mathrm{NO}_{2}^{-}+\mathrm{H}_{3}^{-} \mathrm{O}^{+} \rightarrow \mathrm{NO}_{3}^{-}
\end{aligned}
$$$$
\stackrel{\text { demethylation }}{\longrightarrow}\left(\mathrm{CH}_{3}\right) \mathrm{N}^{+} \mathrm{O} \text {. }
$$

이러한 결과는 $\mathrm{TMAH}$ 가 중간생성물로 전환될 수 있으며 충분한 반응시간이 주어지면 $\mathrm{UV} / \mathrm{S}_{2} \mathrm{O}_{8}{ }^{2-}$ 방법에 의해 $\mathrm{TMAH}$ 가 최종 생성물인 $\mathrm{NH}_{4}{ }^{+}$과 $\mathrm{NO}_{3}{ }^{-}$으로 분해하여 도달함으로써 완전히 분해될 수 있을 것으로 예상한다. ${ }^{15)}$

이와 같이 $\mathrm{TMAH}$ 를 $\mathrm{UV} / \mathrm{S}_{2} \mathrm{O}_{8}{ }^{2-}$ 방법을 적용하여 분해하는 연구가 활발히 수행되어 그에 대한 분해가 가능하다는 것이 증명되었다. 그러나 대부분 $100 \mathrm{mg} / \mathrm{L}$ 이하의 저농도 $\mathrm{TMAH}$ 를 대상으로 한 연구내용이 많고 ${ }^{12,13)} \mathrm{UV} / \mathrm{S}_{2} \mathrm{O}_{8}{ }^{2-}$ 방법으로 $500 \mathrm{mg} / \mathrm{L}$ 이상의 TMAH 분해에 대한 연구는 많지 않은 실정 이다.

TFT-LCD 현상 공정에서 실제로 발생하는 폐수 내 TMAH 가 300 에서 $500 \mathrm{mg} / \mathrm{L}$ 정도가 함유되어 배출되고 있는 것으 로 보고되고 있다. 이와 같은 농도의 TMAH 함유 폐수를 처리하기 위해서 실제 공장에서는 일반적으로 희석방법을 사용하거나 바이오리액터 등의 별도의 처리시스템 사용하 여 1 차 처리 후 유기폐수와 통합 처리하고 있다. 하지만 이러 한 과정은 복잡한 단계를 거치고 별도의 운영비가 발생할 수 있어 고농도의 TMAH를 효율적으로 분해하고 처리하는 데 
어려움이 있다. ${ }^{1)}$ 이처럼 현재 공정에서 배출되는 TMAH 함 유 폐수를 더 효율적으로 처리하는 방법이 필요하며 또한 $\mathrm{TMAH}$ 농도가 높아졌을 때 TMAH 성상이 달라질 것으로 예 상되므로 실제 배출되는 $\mathrm{TMAH}$ 농도를 고려한 $\mathrm{UV} / \mathrm{S}_{2} \mathrm{O}_{8}{ }^{2-}$ 방 법 연구가 진행되어야 할 것으로 판단된다.

본 연구에서는 실제로 배출되는 TMAH 농도를 고려하여 실험농도를 설정하고 이를 분해하기 위해 $\mathrm{UV} / \mathrm{S}_{2} \mathrm{O}_{8}{ }^{2-}$ 방법을 적용하였으며 고농도 $\mathrm{TMAH}$ 분해에 있어 초기 $\mathrm{pH}$, 산화제 농도, 초기 $\mathrm{TMAH}$ 농도에 따른 영향을 평가하여 최적의 처 리조건을 도출하고자 하였다.

\section{2. 실험 재료 및 방법}

\section{1. 실험 재료}

본 실험에서는 $25 \% \mathrm{w} / \mathrm{w}$ TMAH (Tetramethyl ammonium hydroxide, aqueous solution, $>99.9 \%$ ), Potassium persulfate $\left(\mathrm{K}_{2} \mathrm{~S}_{2} \mathrm{O}_{8},>98 \%\right)$, Trimethylamine hydrochloride $\left(\left(\mathrm{CH}_{3}\right)_{3} \mathrm{~N} \cdot\right.$ $\mathrm{HCl}, 98 \%)$, dimethylamine hydrochloride $\left(\left(\mathrm{CH}_{3}\right)_{2} \mathrm{NH} \cdot \mathrm{HCl}\right.$, $99 \%)$, methylamine $\left(\mathrm{CH}_{3} \mathrm{NH}_{2} \cdot \mathrm{HCl}, 98 \%\right)$ 을 Sigma-Aldrich에 서 구입하여 사용하였다. 본 실험을 위해 Fig. 1과 같이 중 간에 UVC lamp (Sankyo G8T5, japan, 8 W (Output 2.5 W), $253.7 \mathrm{~nm}$, Length $287 \mathrm{~mm}$, Diameter $15.5 \mathrm{~mm}$ )를 끼울 수 있도록 지름 $16 \mathrm{~mm}$ 공이 있는 $15 \mathrm{~cm} \times 6 \mathrm{~cm} \times 5.5 \mathrm{~cm}$ 아 크릴 반응기를 제작하여 사용하였다.

\section{2. 실험 방법}

본 연구의 실험은 $25 \% \mathrm{w} / \mathrm{w} \mathrm{TMAH}$ 용액을 희석하여 합 성폐수를 제조하였으며 반응기에 $\mathrm{TMAH}$ 용액 $490 \mathrm{~mL}$ 을 넣고 회분식으로 실험하였다. 총 반응시간은 4시간이며 30 분마다 샘플링하였다. TMAH 분해속도에 영향을 주는 인자 를 찾기 위해 초기 $\mathrm{pH}$, 산화제 주입량, 초기 $\mathrm{TMAH}$ 농도를 각각 변화하여 실험하였다. 초기 $\mathrm{pH}$ 변화 실험은 $750 \mathrm{mg} / \mathrm{L}$ $\mathrm{TMAH}$ 에 $1 \mathrm{~N} \mathrm{H}_{2} \mathrm{SO}_{4}$ 를 사용하여 산성, 중성 조건으로 조절 하였으며 알칼리 조건은 합성폐수 $(\mathrm{pH} 11.05-12.02)$ 그대로 실험하였다. 산화제 주입량 변화 실험은 $750 \mathrm{mg} / \mathrm{L} \mathrm{TMAH}$

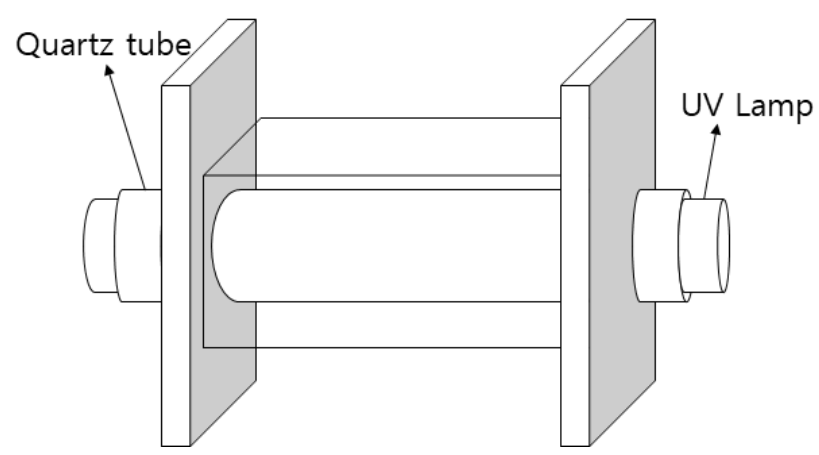

Fig. 1. The schematic of the reactor for $U \mathrm{UV} / \mathrm{S}_{2} \mathrm{O}_{8}{ }^{2-}$.
에 산화제농도를 $0,50,100,150,200 \mathrm{mM}$ 를 주입하여 각각 실험하였고 초기 농도의 영향을 알아보기 위한 실험은 $\mathrm{TMAH}$ 초기 농도를 $100,300,500,700 \mathrm{mg} / \mathrm{L}$ 로 설정한 후 산화제 $100 \mathrm{mM}$ 을 주입하여 실험하였다.

\section{3. 분석방법}

채취한 샘플은 Ion chromatograph (883 basic IC plus, Metrohm, Switzerland)을 이용하여 주요 분석항목을 측정하 였다. TMAH 및 탈메틸화된 중간매개체와 같은 양이온은 컬럼 Metrosep C4 (4-250 mm, Metrohm)를 이용하여 측정 하였으며 이동상은 $3 \mathrm{mM} \mathrm{HNO}{ }_{3}$ 이었다. $\mathrm{NO}_{3}{ }^{-} \mathrm{N}$ 등의 음이 온은 컬럼 Metrosep A Supp 4 (4-250 mm)을 사용하였으며 이동상은 $3.2 \mathrm{mM} \mathrm{Na} \mathrm{CO}_{3}$ 와 $1.0 \mathrm{mM} \mathrm{NaHCO}$ 혼합용액이 었다. $\mathrm{pH}$ 는 $\mathrm{pH}$ meter (Seven Compact $\mathrm{pH}$ meter $\mathrm{S} 220$, METTLER TOLEDO)를 이용하여 샘플링 후 즉시 측정하였다.

\section{3. 결과 및 고찰}

\section{1. 초기 $\mathrm{pH}$ 의 영향}

Fig. 2는 초기 $\mathrm{pH}$ 에 따라 UV만 조사한 것과 persulfate를 첨가하여 조사한 것을 비교한 것이다. 초기 $\mathrm{pH}$ 조절 후 UV 만 조사하였을 때 산과 중성의 초기 상태에서 $\mathrm{TMAH}$ 측정 시 증가와 감소를 반복하였으며 그 범위가 $3 \%$ 내외로 이는 오차로 추정되며 분해가 이루어지지 않았음을 확인할 수 있 었다. 반면 초기 알칼리 상태에서는 $\mathrm{TMAH}$ 농도가 240 분 동안 서서히 감소하여 약 $10 \%$ 가 감소하였으나 이를 모두 제거할 시 많은 시간과 에너지 소모가 필요할 것으로 보인 다. Persulfate를 주입하여 UV를 조사한 TMAH는 산, 중성, 알칼리의 초기 상태에서 240 분 후 각각 $79 \%, 84 \%, 89 \%$ 제 거효율을 보였으며 분해에 초기 $\mathrm{pH}$ 의 영향이 두드러지게 나타났다. 알칼리 상태에서 같은 시간 내 분해효율이 가장

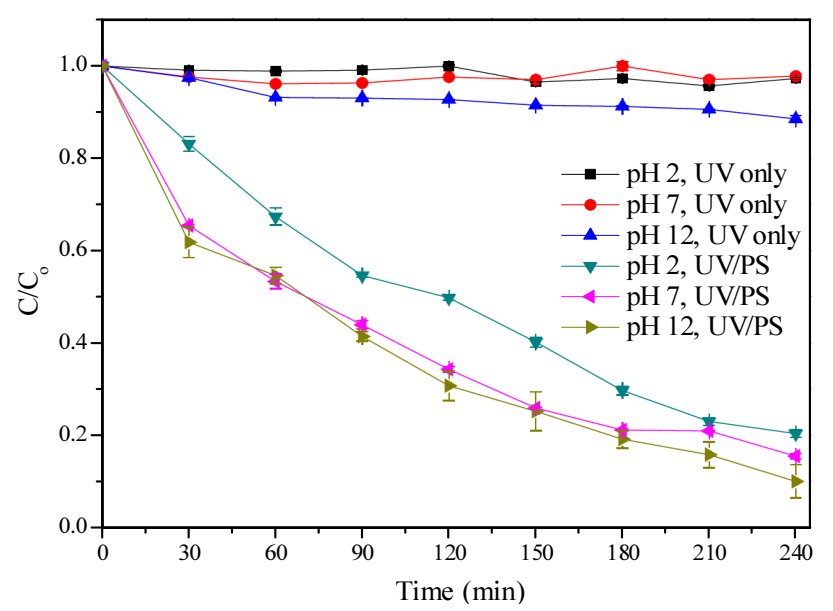

Fig. 2. The degradation of TMAH at different initial $\mathrm{pH}$ during UV only or $\mathrm{UV} / \mathrm{S}_{2} \mathrm{O}_{8}{ }^{2-}$ (PS) ([TMAH] $]_{0}=750 \mathrm{mg} / \mathrm{L}$, persulfate $\left(P S, K_{2} S_{2} \mathrm{O}_{8}\right)=100 \mathrm{mM}, \mathrm{UV}=8 \mathrm{~W}, 240 \mathrm{~min}$ ). 
(a)

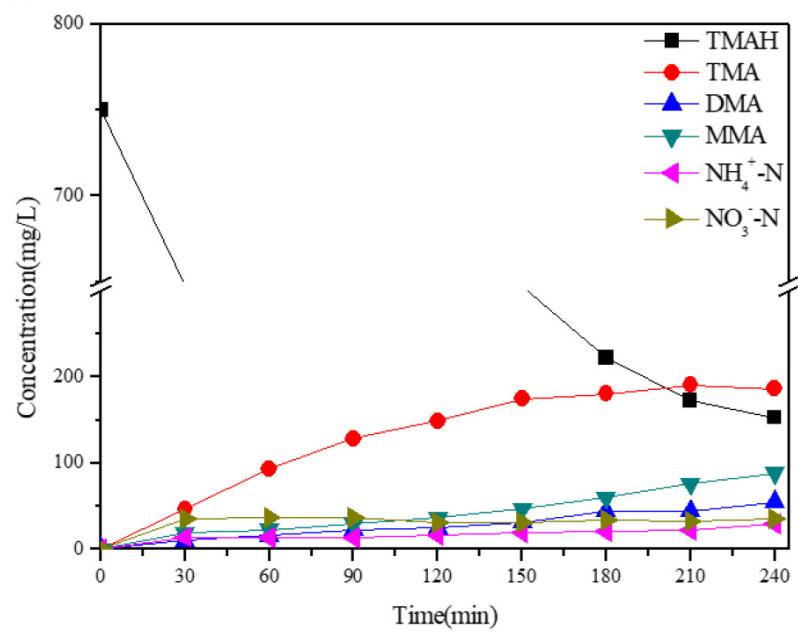

(c)

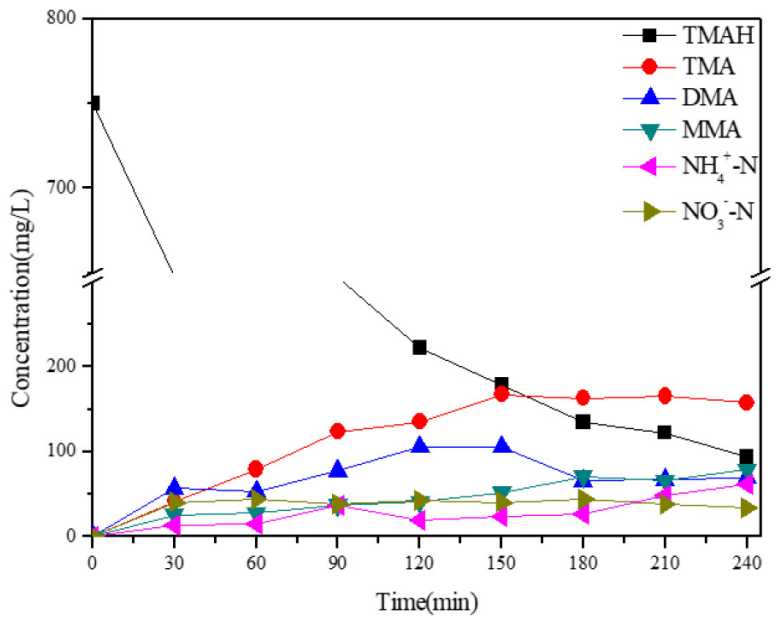

(b)

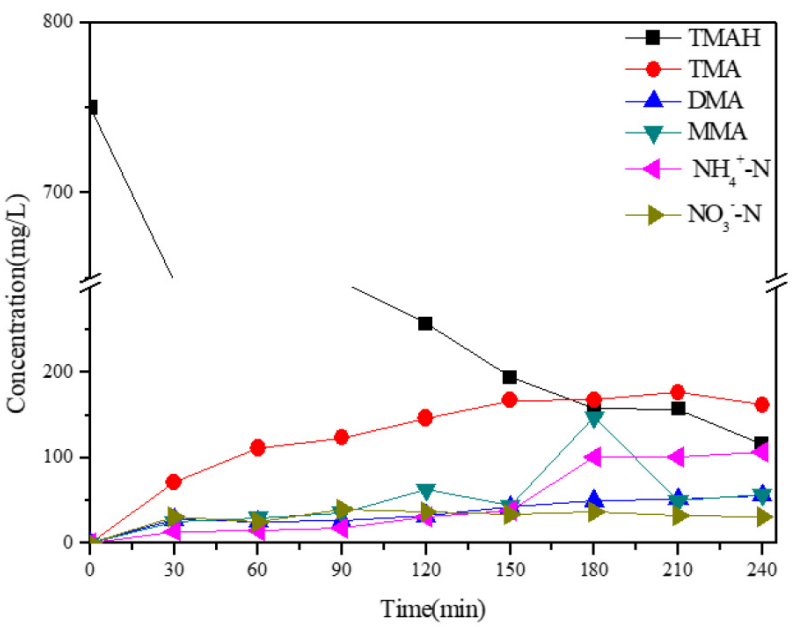

(d)

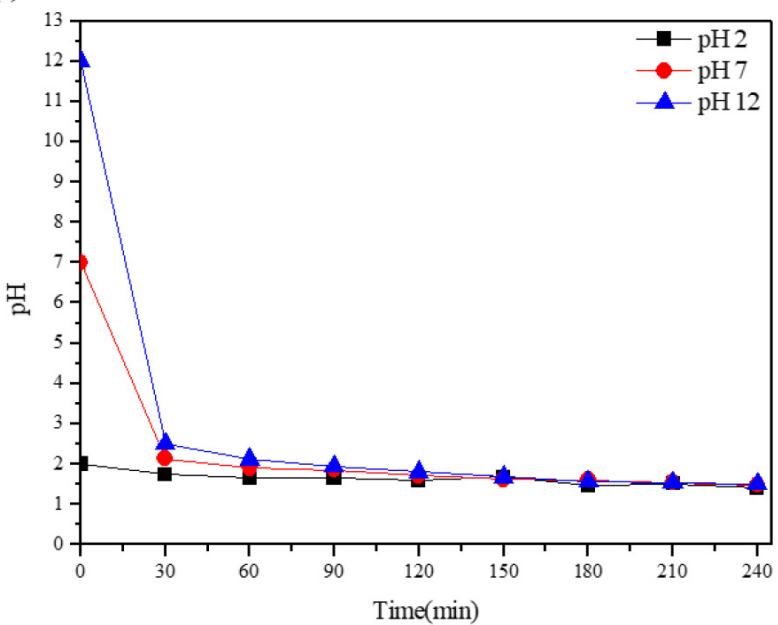

Fig. 3. The degradation of $\mathrm{TMAH}$, formation of intermediates and $\mathrm{pH}$ variation during the oxidation reaction by $\mathrm{UV} / \mathrm{S}_{2} \mathrm{O}_{8}{ }^{2-}$. $((\mathrm{a})$ initial $\mathrm{pH}=2$, (b) initial $\mathrm{pH}=7$, (c) initial $\mathrm{pH}=12$, (d) $\mathrm{pH}$ variation ([TMAH] $]_{0}=750 \mathrm{mg} / \mathrm{L}$, persulfate $\left(\mathrm{K}_{2} \mathrm{~S}_{2} \mathrm{O}_{8}\right)=100$ $\mathrm{mM}, \mathrm{UV}=8 \mathrm{~W}, 240 \mathrm{~min})$.

좋았으며 산 상태보다 약 $10 \%$ 가까이 차이가 났다. 이처럼 초기 알칼리 상태일 때 가장 좋은 제거율을 보였는데 이는 알칼리 상태일 때 Eq. (6)과 같이 persulfate가 UV에 의해 활성화될 때 $\mathrm{SO}_{4}^{-}$과 $\mathrm{HO}^{-}$가 함께 생성되어 분해에 기여함 으로써 제거율이 높아진 것으로 보인다.

Fig. 3은 초기 $\mathrm{pH}$ 에 따른 TMAH 및 중간매개체(TMA, DMA, MMA, $\left.\mathrm{NH}_{4}{ }^{+}-\mathrm{N}, \mathrm{NO}_{3}^{-}-\mathrm{N}\right)$ 의 농도변화를 나타낸 그래 프이다. persulfate를 첨가한 후 UV를 조사하였을 때 TMAH 가 분해되어 농도가 감소하면서 반응부산물들이 생성되었 음을 확인할 수 있었다. TMAH의 분해는 초기에 메틸 그룹 (methyl groups)에서 $\mathrm{SO}_{4}{ }^{-}$공격에 의한 수소이온의 추출 을 통해 일어나며(Eq. (12)), 이는 탄소 중심 라디칼(carbon centered radical)로 이어져 가수분해하여 $\left(\mathrm{CH}_{3}\right)_{3} \mathrm{~N}^{+} \mathrm{CHO}$ (알데 히드 생성물)을 형성한다(Eq. (13)). $\left(\mathrm{CH}_{3}\right)_{3} \mathrm{~N}^{+} \mathrm{CHO}$ 은 이어서 가수분해(Eq. (14)) 또는 추가적인 $\mathrm{SO}_{4}^{-}$공격(Eq. (15), (16)) 으로 TMA 라디칼 형성과 함께 안정적인 TMA 형성으로 이
어져(Eq. (17)) 탈메틸화가 이루어진다. ${ }^{2)}$ 이 과정에서 수소 이온 추출로 인해 용액의 $\mathrm{pH}$ 는 30 분 내 모두 2 이하로 낮아 졌으며 반응이 끝날 때까지 산 상태를 유지하였다.

$$
\begin{aligned}
& \left(\mathrm{CH}_{3}\right)_{4} \mathrm{~N}^{+}+\mathrm{SO}_{4}^{-} \rightarrow\left(\mathrm{CH}_{3}\right)_{3} \mathrm{~N}^{+} \mathrm{CH}_{2}{ }_{2}+\mathrm{H}^{+}+\mathrm{SO}_{4}{ }^{2-} \\
& \left(\mathrm{CH}_{3}\right)_{3} \mathrm{~N}^{+} \mathrm{CH}_{2}^{\cdot}+\mathrm{H}_{3} \mathrm{O}^{+} \rightarrow\left(\mathrm{CH}_{3}\right)_{3} \mathrm{~N}^{+} \mathrm{CHO}+4 \mathrm{H}^{+} \\
& \left(\mathrm{CH}_{3}\right)_{3} \mathrm{~N}^{+} \mathrm{CHO}+\mathrm{H}_{3} \mathrm{O}^{+} \rightarrow\left(\mathrm{CH}_{3}\right)_{3} \mathrm{~N}^{+}+\mathrm{CH}_{2} \mathrm{O}+\mathrm{H}_{2} \mathrm{O} \\
& \left(\mathrm{CH}_{3}\right)_{3} \mathrm{~N}^{+} \mathrm{CHO}+\mathrm{SO}_{4}^{-} \rightarrow\left(\mathrm{CH}_{3}\right)_{3} \mathrm{~N}^{+} \mathrm{CO}+\mathrm{H}^{+}+\mathrm{SO}_{4}{ }^{2-} \\
& \left(\mathrm{CH}_{3}\right)_{3} \mathrm{~N}^{+} \mathrm{CO} \rightarrow\left(\mathrm{CH}_{3}\right)_{3} \mathrm{~N}^{+} \cdot+\mathrm{CO} \\
& \left(\mathrm{CH}_{3}\right)_{3} \mathrm{~N}^{+}+\mathrm{e}^{-}+\mathrm{H}^{+} \rightarrow\left(\mathrm{CH}_{3}\right)_{3} \mathrm{~N}^{+} \mathrm{H}
\end{aligned}
$$

중간생성물은 산성 조건일 때 다소 느리게 분해되어 최종 
Table 1. TMAH degradation rate constants at different conditions during $\mathrm{UV} / \mathrm{S}_{2} \mathrm{O}_{8}{ }^{2-}$. (persulfate $: \mathrm{K}_{2} \mathrm{~S}_{2} \mathrm{O}_{8}$ )

\begin{tabular}{cccc} 
TMAH (mg/L) & initial pH & $\begin{array}{c}\text { persulfate } \\
(\mathrm{mM})\end{array}$ & $\begin{array}{c}k_{\text {obs. TMAH }}\left(\mathrm{R}^{2}\right) \\
\left(\times 10^{-2} \mathrm{~min}^{-1}\right)\end{array}$ \\
& 2 & & $0.66(0.997)$ \\
& 7 & 100 & $0.82(0.990)$ \\
& 12 & & $0.93(0.996)$ \\
750 & & 0 & $0.06(0.931)$ \\
& & 50 & $0.82(0.999)$ \\
& 12 & 100 & $0.93(0.996)$ \\
& & 150 & $0.71(0.998)$ \\
& & 200 & $0.84(0.998)$ \\
300 & & & $4.35(0.993)$ \\
500 & 12 & 100 & $1.86(0.986)$ \\
700 & & & $1.48(0.993)$ \\
& & & $0.86(0.996)$ \\
\hline
\end{tabular}

생성물인 $\mathrm{NH}_{4}{ }^{+} \mathrm{-}$ 으로 진행되는 속도 또한 늦었으며 중성과 알칼리 조건에서는 좀 더 빠른 진행속도를 보였다. 그리고 초기 $\mathrm{pH}$ 가 중성 조건하에서 $\mathrm{TMAH}$ 농도는 알칼리 상태였 을 때보다 덜 감소하였지만 중간생성물의 분해가 150 분 이 후 빠르게 진행되어 가장 높은 $\mathrm{NH}_{4}{ }^{+}-\mathrm{N}$ 가 생성되었으며 알 칼리 조건일 때는 반응시간 초반부터 DMA, MMA로의 탈 메틸반응이 빠르게 진행되었으나 이후 진행은 느려져 초기 $\mathrm{pH}$ 중성 조건하에서 $\mathrm{NH}_{4}{ }^{+} \mathrm{N}$ 의 농도보다 낮게 측정되었다.

Table 1은 $\log$ plot의 기울기를 이용하여 1차 반응속도 상 수 $\left(k_{\mathrm{obs}, \mathrm{TMAH}}\right)$ 값을 계산하여 각 조건별 반응속도를 나타낸 것 이다. 합성폐수 내 잔존하는 TMAH 농도를 초기 농도로 나 눠주고, 이 값에 $\log$ 를 취하여 시간에 따라 나열한 후 추세 선을 첨가하여 기울기값을 구해 그 값을 반응속도상수값 $\left(k_{\mathrm{obs}, \mathrm{TMAH}}\right)$ 으로 도출한 것으로 초기 $\mathrm{pH}$ 가 높아질수록 반응 속도상수 또한 높아진 것을 확인할 수 있었다.

이와 같이 $\mathrm{UV} / \mathrm{S}_{2} \mathrm{O}_{8}{ }^{2-}$ 공정에서 $\mathrm{pH}$ 는 중요한 인자로 작용한 다. persulfate 활성화 시 산성의 $\mathrm{pH}$ 에서는 $\mathrm{SO}_{4}^{-}{ }^{-}$이 우선적으 로 반응하나 알칼리 $\mathrm{pH}$ 에서는 앞선 식에 따라 $\mathrm{HO}^{-}$가 우세 하게 된다. 이전의 연구에서는 TMAH를 UV/persulfate 공정 으로 처리할 때 $\mathrm{pH}$ 가 산일 때 제거율이 높고 알칼리 상태에 서는 그보다 낮은 것으로 나타났는데 수소추출과 전자전달 을 거치는 $\mathrm{SO}_{4}{ }^{-}$가 $\mathrm{HO}^{-}$보다 유기물에 더 선택적으로 반응 하면서 $\mathrm{SO}_{4}^{-*}$ 가 우세하게 반응하는 산성 $\mathrm{pH}$ 에서 $\mathrm{TMAH}$ 분 해도가 높게 나타난 것이다. 또한 용액의 $\mathrm{pH}$ 가 높아질 때 $\mathrm{SO}_{4}{ }^{-}$이 $\mathrm{OH}^{-}$와 반응하여 $\mathrm{HO}^{*}$ 로 전환되고 $\mathrm{pH}$ 가 더 높아지 면 $\mathrm{SO}_{4}{ }^{-}$은 거의 사라지게 되어 이렇게 생성된 $\mathrm{HO}^{*}$ 은 용 액 내 다량 존재하는 $\mathrm{SO}_{4}{ }^{2-}$ 에 의해 제거되어 처리효율이 낮 아질 수 있기 때문이다. $\mathrm{HO}^{*}$ 는 질소를 함유하고 있는 화합 물에서 탄화수소 분자의 분해하고 질소화합물 안에 비공유 전자쌍(lone-pair electron)를 공격할 수 있다. 이러한 특성을
지닌 $\mathrm{HO}^{\circ}$ 임에도 $\mathrm{TMAH}$ 에 대한 반응성이 저하되는 것은 $\left(\mathrm{CH}_{3}\right)_{4} \mathrm{~N}^{+}(\mathrm{TMAH})$ 는 비공유전자쌍이 없기 때문에 $\mathrm{UV} / \mathrm{S}_{2} \mathrm{O}_{8}{ }^{2-}$ 공정에서 $\mathrm{HO}^{*}$ 에 의한 분해 속도가 상대적으로 느리게 되는 것이다. 이에 반해 $\mathrm{SO}_{4}{ }^{-}$는 쉽게 수소원자를 추출하는 경향 이 있어 TMAH가 비공유전자쌍이 없어도 분해할 수 있는 유 리한 경로가 되기도 한다. 따라서 $\mathrm{HO}^{*}\left(E^{0} 2.7 \mathrm{~V}\right)$ 가 $\mathrm{SO}_{4}{ }^{-}$ $\left(E^{0} 2.4 \mathrm{~V}\right)$ 보다 높은 산화환원전위를 가지고 있더라도 선택 성이 $\mathrm{SO}_{4}^{-}$가 더 우세하기 때문에 TMAH의 제거가 덜 발생 할 수 있다. ${ }^{8,12,13)}$ 본 실험에서는 초기 $\mathrm{pH}$ 가 중성 이상의 조건 에서 제거율이 좋았고 반응부산물의 생성 및 분해가 다른 것 을 확인할 수 있었는데 이는 초기 농도가 $750 \mathrm{mg} / \mathrm{L}$ 으로 이전 의 실행된 농도보다 높아지면서 분해속도가 느려지고 $\mathrm{OH}^{-}$와 반응하여 $\mathrm{HO}^{*}$ 가 생성되는 $\mathrm{pH}$ 시작점 또는 통과하는 지점에 서 $\mathrm{SO}_{4}^{-}$와 $\mathrm{HO}^{-}$가 동시에 생성되면서 함께 분해에 기여하여 반응속도상수 및 분해효율이 더 큰 것으로 판단된다. 또한 초 기에 이 반응이 이루어져 후반까지 영향을 미친 것으로 추측 되며 실제로 $\mathrm{pH}$ 가 산을 유지할 때는 분해속도가 비슷하였다. 그리고 TMAH 분해 후 발생되는 반응부산물(TMA, DMA, $\mathrm{MMA}$ )은 질소 원자의 고립전자쌍을 상태가 되어 $\mathrm{HO}^{*}$ 가 유 리하게 공격할 수 있으며 $\mathrm{HO}^{*}$ 가 생성되는 중성 이상의 조건 에서 반응생성물의 분해가 잘 이루어진 것으로 판단된다.

\section{2. 산화제 주입량의 영향}

산화제 주입량에 대한 실험은 초기 알칼리 조건에서 실험 을 진행하였으며 그에 대한 결과 Fig.4에 나타내었다. 산화 제를 주입하지 않은 TMAH는 거의 농도의 변화가 없었으 며 산화제를 주입한 $\mathrm{TMAH}$ 는 $\mathrm{UV}$ 를 조사한 후 빠르게 농도 가 감소하였다. $50,100,150,200 \mathrm{mM} \mathrm{K} \mathrm{S}_{2} \mathrm{O}_{8}$ 주입 시 각각 약 $85 \%, 87 \%, 83 \%, 86 \%$ 의 처리효율을 나타내 $100 \mathrm{mM}$ 산 화제 주입 시 가장 처리효율이 높았으며 반응속도상수 또한

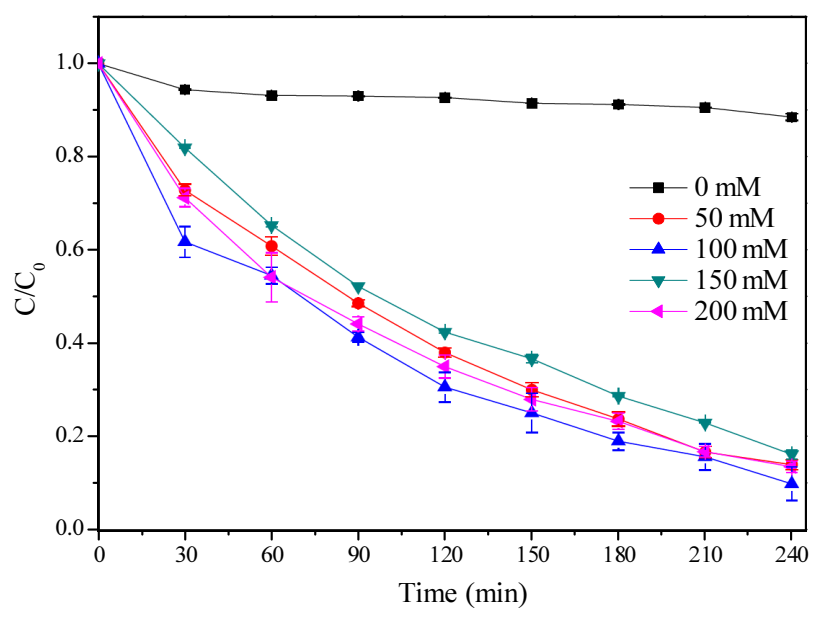

Fig. 4. The degradation of TMAH at different amount of an addition of persulfate $\left(\mathrm{K}_{2} \mathrm{~S}_{2} \mathrm{O}_{8}\right)$ the oxidation reaction by $\mathrm{UV} / \mathrm{S}_{2} \mathrm{O}_{8}{ }^{2-}$. ([TMAH $]_{0}=750 \mathrm{mg} / \mathrm{L}$, Initial $\mathrm{pH}=12$, $\mathrm{UV}=8 \mathrm{~W}, 240 \mathrm{~min}$ ) 
가장 빨라 분해속도가 가장 빠른 것으로 나타났다(Table 1) 그리고 $150 \mathrm{mM}$ 이상의 산화제 주입량에서는 그보다 처리 효율이 떨어지는 것을 확인할 수 있었다. Wang과 Liang은 $\mathrm{TMAH}$ 를 $\mathrm{UV} / \mathrm{S}_{2} \mathrm{O}_{8}{ }^{2-}$ 를 이용하여 분해할 때 과량의 산화제 를 주입하면 TMAH 분해를 저해할 수 있다고 보고하였는 데 ${ }^{12)}$ 이와 같이 UV 조사하에 persulfate의 주입량이 많아질 수록 $\mathrm{SO}_{4}{ }^{-}$의 양이 많아지게 되어 오히려 $\mathrm{S}_{2} \mathrm{O}_{8}{ }^{2-}$ 와 $\mathrm{SO}_{4}{ }^{-}$을 제거하게 되어(Eq. (18), (19)) 분해효율이 떨어지는 것으로 본 실험의 결과에서도 이러한 현상이 나타난 것으로 추측된 다. 따라서 설정농도에 대한 최대분해효율을 가지기 위해서 는 TMAH를 분해할 수 있는 요소의 손실이 없도록 적합한 양의 산화제를 주입해 주어야 할 것으로 보인다.

$$
\begin{array}{ll}
\mathrm{SO}_{4}{ }^{-}+\mathrm{S}_{2} \mathrm{O}_{8}{ }^{2-} \rightarrow \mathrm{SO}_{4}{ }^{2-}+\mathrm{S}_{2} \mathrm{O}_{8}{ }^{-\cdot} & k=6.1 \times 10^{5} \mathrm{M}^{-1} \mathrm{~s}^{-1} \\
\mathrm{SO}_{4}{ }^{-}+\mathrm{SO}_{4}^{-} \rightarrow \mathrm{S}_{2} \mathrm{O}_{8}{ }^{2-} & k=4 \times 10^{8} \mathrm{M}^{-1} \mathrm{~s}^{-1}
\end{array}
$$

\section{3. 초기 TMAH 농도의 영향}

초기 TMAH 농도에 대해 240 분 반응 시 분해효율을 Fig. 5 에 나타내었다. 초기농도가 $100 \mathrm{mg} / \mathrm{L}$ 일 때에 30 분에 절반 이상 농도가 감소하여 150 분 이내에 모두 분해되었다. 300 , $500,700 \mathrm{mg} / \mathrm{L}$ 에서 각각 $99 \%, 97 \%, 86 \%$ 분해되었으며 초 기농도가 높을수록 분해효율이 낮았고 반응속도상수 또한 낮아지는 경향을 보였다. $100 \mathrm{mg} / \mathrm{L}$ 일 때는 30 분에 이미 절 반 이상의 감소하며 가파른 감소폭을 보였고 300 과 500 $\mathrm{mg} / \mathrm{L}$ 에서는 30 분 감소가 차이가 났지만 그 후 같은 감소진 행을 보여 산화제 소모 및 반응이 비슷할 것으로 추측되었 고 $700 \mathrm{mg} / \mathrm{L}$ 는 120 분까지는 원만한 감소를 보였으나 이후 반응할 산화제의 감소로 감소속도가 점점 느려지는 경향을 보였다.

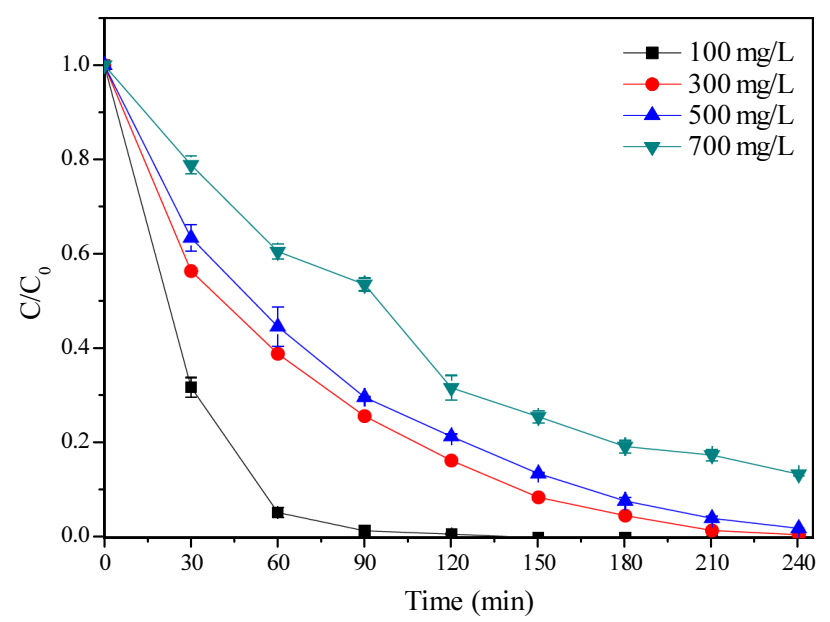

Fig. 5. The degradation of TMAH at different initial TMAH concentration $(100,300,500,700 \mathrm{mg} / \mathrm{L})$ during $\mathrm{UV} / \mathrm{S}_{2} \mathrm{O}_{8}{ }^{2-}$. (persulfate $\left(\mathrm{K}_{2} \mathrm{~S}_{2} \mathrm{O}_{8}\right)=100 \mathrm{mM}, \mathrm{UV}=8 \mathrm{~W}$, $240 \mathrm{~min}$ )
Table 2. Variation of $\mathrm{pH}$ at different initial TMAH concentration during $\mathrm{UV} / \mathrm{S}_{2} \mathrm{O}_{8}{ }^{2-}$.

\begin{tabular}{ccccc} 
& \multicolumn{4}{c}{ TMAH Conc. (mg/L) } \\
\cline { 2 - 5 } Time $(\mathrm{min})$ & 100 & 300 & 500 & 700 \\
\hline 0 & 11.05 & 11.56 & 11.75 & 12.02 \\
30 & 2.2 & 2.22 & 2.28 & 2.37 \\
60 & 1.89 & 2.01 & 1.9 & 1.99 \\
90 & 1.82 & 1.86 & 1.78 & 1.84 \\
120 & 1.78 & 1.75 & 1.69 & 1.75 \\
150 & 1.76 & 1.65 & 1.57 & 1.65 \\
180 & 1.74 & 1.6 & 1.53 & 1.54 \\
210 & 1.69 & 1.55 & 1.5 & 1.54 \\
240 & 1.7 & 1.52 & 1.46 & 1.49 \\
\hline
\end{tabular}

Table 2는 초기 TMAH 농도에 따른 반응 시 $\mathrm{pH}$ 변화를 나타낸 것이다. 초기 농도가 높을수록 $\mathrm{pH}$ 는 높게 측정되었 으며 이후 초기농도에 따라 $\mathrm{pH}$ 의 변화가 다르게 나타났다. $100 \mathrm{mg} / \mathrm{L}$ 에서는 초기 60 분까지 분해가 빨리 이루어지면서 수소이온 추출이 활발해 $\mathrm{pH}$ 가 가장 낮게 측정되었고 150 분 에 TMAH가 모두 분해됨에 따라 더 이상 반응하지 않아 $\mathrm{pH}$ 의 감소폭이 줄어든 것으로 판단된다. 그리고 나머지는 초기 TMAH 농도에서는 TMAH가 산화제 반응하여 계속 분해되면서 수소이온이 발생하여 낮아진 것으로 보인다. 이 에 따라 초기 TMAH 농도는 산화제 주입량을 선정하는 기 준이 될 것이며 $\mathrm{TMAH}$ 농도가 증가할수록 $\mathrm{TMAH}$ 분해에 필요한 산화제 소모가 증가되어야 빠르게 분해될 수 있으며 최대의 분해효율을 얻을 수 있으므로 실제 공장에서 배출되 는 $\mathrm{TMAH}$ 의 농도를 정확히 파악하는 것이 중요할 것으로 사료된다.

\section{4. 에너지효율 비교}

$\mathrm{TMAH}$ 을 분해하기 위해 적용한 조건으로 UV를 조사하 였을 때 에너지효율을 평가하기 위해 Electrical energy per $\operatorname{order}(\mathrm{EE} / \mathrm{O})$ 을 계산하여 비교하였다. $\mathrm{EE} / \mathrm{O}$ 는 $1 \mathrm{~m}^{3}$ 의 부피 에서 목표오염물질을 분해하는데 UV lamp가 소비하는 전 기에너지 $(\mathrm{kWh})$ 로 정의되며 $\mathrm{EE} / \mathrm{O}$ 의 값이 작을수록 공정이 더 효율적이고 경제적이다. $\mathrm{EE} / \mathrm{O}$ 는 다음과 같은 식으로 나 타낼 수 있다(Eq. (20)). ${ }^{13,17,18)}$

$$
\begin{aligned}
& \mathrm{EE} / \mathrm{O}\left(\mathrm{kWh} / \mathrm{m}^{3} / \text { order }\right)=\frac{P \cdot t \cdot 1000}{V \cdot 60 \cdot \log \left(\frac{C_{0}}{C_{t}}\right)} \\
& P: \text { Lamp power }(\mathrm{kW}) \\
& t: \mathrm{UV} \text { irradiation time }(\mathrm{min}) \\
& V: \text { Reactor volume }(\mathrm{L}) \\
& C_{0}: \text { Initial concentration } \\
& C_{t}: \text { Final concentration }
\end{aligned}
$$




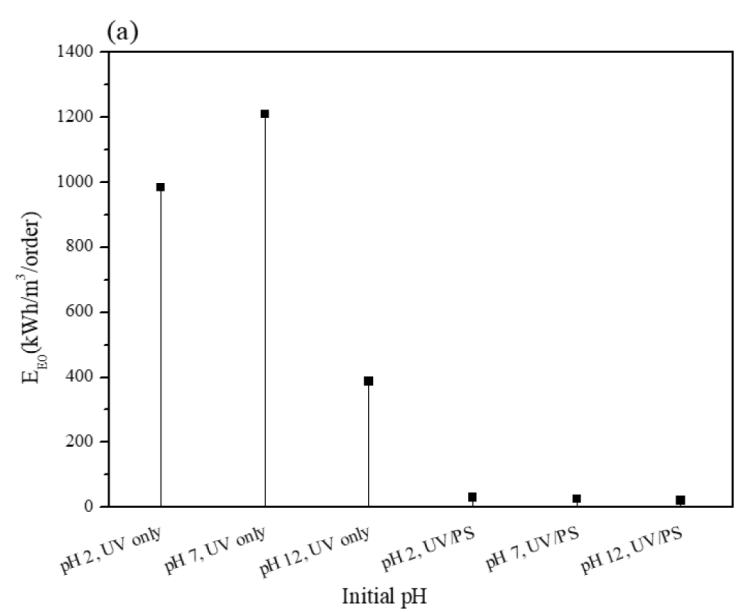

(b)
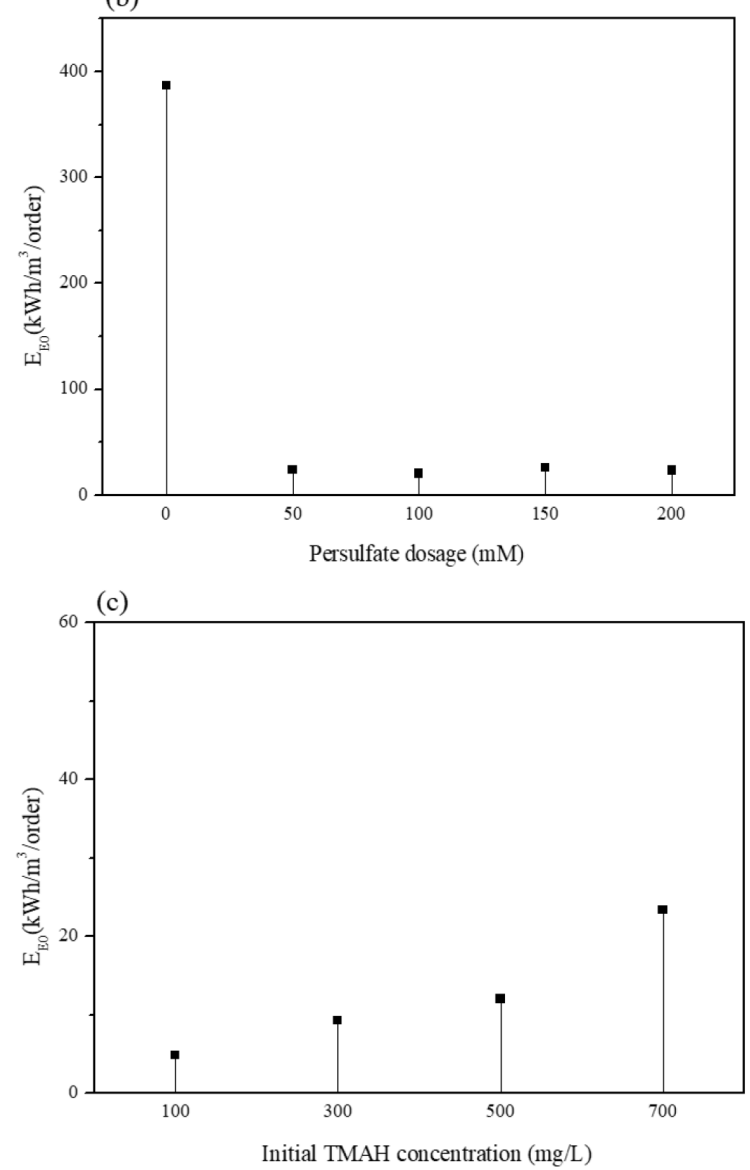

Fig. 6. Comparison of Electrical energy per order ( $\mathrm{kWh} / \mathrm{m}^{3} /$ order) at different condition for the degradation of TMAH by $\mathrm{UV} / \mathrm{S}_{2} \mathrm{O}_{8}{ }^{2-}:$ (a) initial $\mathrm{pH}$ (du ring UV only or $\mathrm{UV} / \mathrm{S}_{2} \mathrm{O}_{8}{ }^{2-}$ (PS), $[\mathrm{TMAH}]_{0}=750 \mathrm{mg} / \mathrm{L}$, persulfate $\left(\mathrm{PS}, \mathrm{K}_{2} \mathrm{~S}_{2} \mathrm{O}_{8}\right)=$ $100 \mathrm{mM}),\left(\right.$ b) persulfate dosage $\left([\mathrm{TMAH}]_{0}=750 \mathrm{mg} / \mathrm{L}\right.$, initial $\mathrm{pH}=12$ ), (c) Initial concentration (persulfate = $100 \mathrm{mM}$, initial $\mathrm{pH}=12$ ).

Fig.6은 초기 $\mathrm{pH}$, 산화제 주입량, 초기 농도의 조건을 적용 하여 같은 시간에 분해하였을 때 위의 계산식을 통해 얻어낸 $\mathrm{EE} / \mathrm{O}$ 값을 비교한 그래프이다. 조건에 따라 $\mathrm{EE} / \mathrm{O}$ 값의 추이 를 확인할 수 있었다. 초기 $\mathrm{pH}$ 설정 후 UV를 단독으로 조
사한 것과 persulfate를 주입하여 UV를 조사하였을 때의 결과를 Fig.6(a)에 나타내었는데 초기 $\mathrm{pH}$ 가 알칼리 상태 에서 산화제를 주입하고 UV를 조사하였을 때 20.46 $\mathrm{kWh} / \mathrm{m}^{3} / \mathrm{order}$ 로 계산되어 가장 낮았고 초기 $\mathrm{pH}$ 중성 상태에 서 UV 단독 조사일 때 $1,209.94 \mathrm{kWh} / \mathrm{m}^{3} /$ order로 가장 높은 값을 보여 높은 농도의 TMAH에서 반응도가 좋은 산화제를 주입하여 에너지 효율을 높일 수 있음과 초기 $\mathrm{pH}$ 에 따라 서 로 상이하며 산화제 주입 시 초기 $\mathrm{pH}$ 가 높아질수록 반응속 도상수가 증가하여 $\mathrm{EE} / \mathrm{O}$ 값이 낮아지는 반비례관계를 보였 다. $750 \mathrm{mg} / \mathrm{L}$ 의 $\mathrm{TMAH}$ 를 각각 다른 산화제 주입량에 따른 $\mathrm{UV}$ 분해에 대한 EE/O값을 계산하여 Fig.6(b)에 나타내었다. 산화제를 주입함으로써 처리효율과 더불어 반응속도를 높일 수 있어 에너지효율이 높아지는 경향을 보였으며 persulfate $100 \mathrm{mM}$ 를 주입하였을 때 $\mathrm{EE} / \mathrm{O}$ 값이 가장 작아 $750 \mathrm{mg} / \mathrm{L}$ 의 $\mathrm{TMAH}$ 에 대한 에너지효율이 가장 높아 최적의 산화제 주입 량을 도출할 수 있었다. 이와 반대로 오염물질의 초기 농도 가 $100 \mathrm{mg} / \mathrm{L}$ 에서 $700 \mathrm{mg} / \mathrm{L}$ 으로 증가할수록 $\mathrm{EE} / \mathrm{O}$ 값이 증가 하는 정비례 관계를 보였다. 이는 분해 과정에서 동일한 산화 제 주입량이 초기 $\mathrm{TMAH}$ 농도가 높아질수록 산화력이 약화 되어 처리효율이 낮아지는 것이 확인되면서 이에 대해 반응 속도가 낮아져 $\mathrm{EE} / \mathrm{O}$ 값이 크게 나타난 것으로 보인다. 낮은 $\mathrm{EE} / \mathrm{O}$ 값은 반응속도가 높아짐에 기인하기 때문에 이와 같은 결과를 토대로 초기 $\mathrm{pH}$ 를 높이거나 초기 TMAH 농도에 대 한 반응도를 고려한 최적의 산화제를 주입하여 반응속도를 높일 수 있을 것으로 판단된다.

\section{4. 결 론}

본 연구에서는 TFT-LCD 제조공정에서 배출되는 $750 \mathrm{mg} / \mathrm{L}$ 의 $\mathrm{TMAH}$ 를 분해하기 위해 $\mathrm{TMAH}$ 합성폐수에 $\mathrm{UV} / \mathrm{S}_{2} \mathrm{O}_{8}{ }^{2-}$ 을 적용하여 초기 $\mathrm{pH}$, 산화제 농도, 초기 $\mathrm{TMAH}$ 농도에 따른 제거효율을 비교하여 $\mathrm{TMAH}$ 의 제거를 위한 최적 반응조건 을 구하고자 하였다. $\mathrm{UV} / \mathrm{S}_{2} \mathrm{O}_{8}{ }^{2-}$ 방법을 이용하여 $750 \mathrm{mg} / \mathrm{L}$ 의 $\mathrm{TMAH}$ 의 제거반응에서 초기 $\mathrm{pH}$ 와 관계없이 제거가 이루어 졌으며 초기 $\mathrm{pH}$ 가 높아질수록 제거효율이 상승하였으며 초 기 $\mathrm{pH} 12$ 에서 $89 \%$ 로 제거효율이 가장 높게 나타났다. 이는 알칼리 상태에서 persulfate를 UV로 활성화하였을 때 $\mathrm{H}_{2} \mathrm{O}$ 또 는 $\mathrm{OH}^{-}$와 반응하여 전환된 $\mathrm{HO}^{\circ}$ 와 $\mathrm{SO}_{4}^{-}$가 함께 분해에 기여 하여 제거효율이 상승한 것으로 보이며 반응속도상수 또한 가장 높게 나타났다. 또한 $\mathrm{TMAH}$ 농도가 감소하면서 중간생성 물들이 생성되었고 초기 $\mathrm{pH}$ 에 따라 중간생성물 생성 속도와 경향이 다른 것으로 확인되었다. 이에 따라 $\mathrm{pH}$ 조절을 하지 않 아도 $90 \%$ 에 가까운 처리효율을 기대할 수 있을 것으로 보이며 중간매개체 또한 초기 $\mathrm{pH}$ 의 영향을 받는 것으로 판단된다.

산화제를 주입하지 않았을 때는 $\mathrm{TMAH}$ 농도변화가 거의 없었으며 $50,100,150,200 \mathrm{mM} \mathrm{K}_{2} \mathrm{~S}_{2} \mathrm{O}_{8}$ 주입 시 처리효율 은 각각 약 $85 \%, 87 \%, 83 \%, 86 \%$ 으로 $100 \mathrm{mM}$ 일 때 가장 
높았으며 $150 \mathrm{mM}$ 의 산화제 주입에서는 오히려 처리효율이 낮게 나타났다. 이 결과는 UV 조사하에 persulfate 주입량이 많아질수록 과량으로 생산된 $\mathrm{SO}_{4}{ }^{-}$가 $\mathrm{S}_{2} \mathrm{O}_{8}{ }^{2-}$ 와 $\mathrm{SO}_{4}{ }^{-}$를 제 거하게 되어 분해효율이 떨어질 수도 있다는 선행 연구와 일치하였으며 $500 \mathrm{mg} / \mathrm{L}$ 이상의 TMAH에서는 산화제 과주 입으로 인한 방해현상을 줄이고 반응농도에 최적량의 산화제 를 주입하여 보다 효율적으로 분해할 수 있어야 할 것이다.

초기 TMAH 농도에 대한 영향은 $100 \mathrm{mg} / \mathrm{L}$ 일 때 빠르게 제거되어 150 분 이내 모두 감소하였고 $300,500,700 \mathrm{mg} / \mathrm{L}$ 에서 각각 $99 \%, 97 \%, 86 \%$ 로 초기농도가 높아질수록 제거 효율 및 반응속도상수가 낮아지는 경향을 보였다.

에너지 효율을 평가하기 위해 $\mathrm{EE} / \mathrm{O}$ 값을 계산하여 비교하 였다. $750 \mathrm{mg} / \mathrm{L}$ 의 $\mathrm{TMAH}$ 를 분해할 때 초기 $\mathrm{pH}$ 12에서 산 화제 주입하였을 때 같은 시간 내의 $\mathrm{EE} / \mathrm{O}$ 값이 가장 작았다. 그러나 농도가 높아질수록 산화력 저하로 $\mathrm{EE} / \mathrm{O}$ 값이 높아 지기 때문에 초기 $\mathrm{TMAH}$ 농도와 반응성이 적절한 양의 산 화제를 주입하여 에너지효율을 보완할 수 있을 것으로 판 단된다.

\section{References}

1. Y. T. Huh, A study for optimum treatment of TN wastewater including TMAH in LCD industry, Graduate School of Industry, Kyungpook National University(2011).

2. C. N. Lei, L. M. Whang, P. C. Chen, Biological treatment of thin-film transistor liquid crystal display (TFT-LCD) wastewater using aerobic and anoxic/oxic sequencing batch reactors, Chemosphere, 81(1), 57-64(2010).

3. K. F. Chang, S. Y. Yang, H. S. You, J. R. Pan, Anaerobic treatment of tetra-methyl ammonium hydroxide (TMAH) containing wastewater, semiconductor manufacturing, IEEE Trans. Semicond. Manuf., 21(3), 486-491(2008).

4. K. Hirano, J. Okamura, T. Taira, K. Sano, A. Toyoda, M. Ikeda, An efficient treatment technique for TMAH wastewater by catalytic oxidation, IEEE Trans. Semicond. Manuf, 14(3), 202-206(2001).

5. S. Kim, W. Choi, Kinetics and mechanisms of photocatalytic degradation of $(\mathrm{CH} 3)_{\mathrm{n}} \mathrm{NH}_{4-\mathrm{n}}{ }^{+}(0 \leq \mathrm{n} \leq 4)$ in $\mathrm{TiO}_{2}$ suspension: the role of $\mathrm{OH}$ radicals, Environ. Sci. Technol., 36(9), 2019-2025(2002).

6. H. M. Citraningrum, J. C. Liu, J. M Chern, Removal of tetramethylammonium hydroxide from solution using ion exchange, IEEE Trans. Semicond. Manuf., 26(2), 214-220 (2013).

7. H. Kim, S, Do, K. Park, Y. Jo, S. Kong, Degradation of TCE by persulfate oxidation with various activation methods (heat, $\mathrm{Fe}^{2+}$, and UV) for ex-situ chemical oxdiation processes, J. Soil Groundwater Environ., 17(6), 43-51(2012).

8. K. Song, S. Do, H. Lee, Y. Jo, S. Kong, A study on persulfate oxidation to remove chlorinated solvents (TCE/PCE), J. Korean Soc. Environ. Eng., 31(7), 549-556(2009).
9. C. Liang, I. Lee, In situ iron activated persulfate oxdative fluid sparging treatment of TCE contamination-a proof of concept study, J. Contam. Hydrol., 100(3-4), 91-100(2008).

10. J. Wang, S. Wang, Activation of persulfate (PS) and peroxymonosulfate (PMS) and application for the degradation of emerging contaminants, Chem. Eng. J., 334, 1502-1517(2018).

11. W. Song, J. Li, Z. Wang, X. Zhang, A mini review of activated methods to persulfate-based advanced oxidation process, Water Sci. Technol., 79(3), 573-579(2019).

12. N. S. Shah, X. He, H. M. Khan, J. A. Khan, K. E. O'Shea, D. L. Boccelli, D. D. Dionysiou, Efficient removal of endosulfan from aqueous solution by UV-C/peroxides: a comparative study, J. Hazardous Materials, 263(Part 2), 584-592(2013).

13. X. He, A. A. de la Cruz, D. D. Dionysiou, Destuction of cyanobaterial toxin cylindrospermopsin by hydroxyl radicals and sulfate radicals using UV-254 $\mathrm{nm}$ activation of hydrogen peroxide, persulfate and peroxymonosulfate, J. Photochem. Photobiol., A, 251, 160-166(2013).

14. M. G. Antoniou, P. A. Nicolaou, J. A. Shoemaker, A. A. de la Cruz, D. D. Dionysiou, Impact of the morphological properties of thin $\mathrm{TiO}_{2}$ photocatalytic films on the detoxification of water contaminated with the cyanotoxin, microcystin-LR, Appl. Catal., B, 91(1-2), 165-173(2009).

15. C. Wang, C. Liang, Oxidative degradation of TMAH solution with UV persulfate activation, Chem. Eng. J., 254, 472-478(2014).

16. J. Huang, K. Wang, C. Liang, Oxidative degradation of tetramethylammonium hydroxide (TMAH) by UV/persulfate and associated acute toxicity assessment, J. Environ. Sci. Health, Part A., 52(9), 930-937(2017).

17. Y. Xiao, L. Zhang, W. Zhang, K. Lim, R. D. Webster, T. Lim, Comparative evaluation of iodoacids removal by $\mathrm{UV} /$ persulfate and $\mathrm{UV} / \mathrm{H}_{2} \mathrm{O}_{2}$ processes, Water Res., 102, 629-639(2016).

18. M. A. Behnajady, N. Modirshahla, Evaluation of electrical energy per order $\left(E_{\mathrm{EO}}\right)$ with kinetic modeling on photooxidative degradation of C. I. acid orange 7 in a tubular continuous-flow photoreactor, Ind. Eng. Chem. Res., 45(2), 553-557(2006).

\section{Authors}

\section{Hyoyeon Choi}

Department of Environmental Energy Engineering, Graduate School of Energy \& Environment, Seoul National University of Science \& Technology, Ph. D. Candidate, ORCiD (다 0000-00026423-8419

\section{Daewon Pak}

Department of Environmental Energy Engineering, Graduate School of Energy \& Environment, Seoul National University of Science \& Technology, Professor, ORCID @ 0000-0002-8664-1946 